\title{
Microbiological quality analysis of commercial fruit juice in Dhaka City, Bangladesh
}

\author{
Md. Al-Amin, Mofijur Rahman Mamun and Kamal Kanta Das* \\ Department of Microbiology, Stamford University Bangladesh, 51, Siddeswari Road, Dhaka 1217, Bangladesh
}

Received 16 April 2018/Accepted 21 May 2018

\begin{abstract}
The aims of this study were to evaluate the microbiological quality of different commercially available fruit juice of Dhaka city. In this study total 20 fruit juice samples of five different types were repeatedly subjected to bacteriological and mycological screening for three months. Isolates were identified and confirmed using cultural and biochemical characteristics. Current study showed high bacterial and fungal loads consisting of specific pathogens such as coliform and Staphylococcus spp., fecal coliform and other pathogens are totally absent. The presence of Staphylococcus aureus portends health risk to consumers as some species produce potent toxins associated with food borne illnesses. And high bacterial count indicated unhygienic conditions of the processing area, and that good manufacturing practices during processing are not maintained properly. Recommendations are required to reduce the microbiological contamination and promote quality assurance of the products.
\end{abstract}

Key words: Fruit juice; Microbiological quality; Public health

Fruit juices are most common refreshing drinks in summer season (1). They taste good and also contain nutrients (1-3). Juices are fat-free and contain naturally occurring phytonutrients, antioxidant, vitamins and minerals which are essential elements for better health. Eventually it becomes an important part of the modern human diet (4-5). Vitamin $\mathrm{C}$ in orange juice acts as an antioxidant photochemical which help to improve the blood lipid profiles in hyper-cholesteromic patients (6). Fruit juices promote detoxification in the human body (7).

Fruit juices are available in packed form in different concentration though out the year. As fresh juice, they also rich in nutrient and to ensure the microbiological quality as well as same taste, color and aroma of fresh juice food industry employ pasteurization, sterilization or addition of preservative to fruit juice $(1,8-10)$. But different pathogenic microbes can get entry to packed juice during processing, packaging and handling (11). Different studies on fruit juice around the world reported that consumption of contaminated juices is responsible for number of diseases $(1,12-16)$. As juice contain high amount of nutrients and sugar make juice more susceptible to microbial contamination $(1-3,18)$. But to prevent microbial growth, several factors such as $\mathrm{pH}$, temperature and concentration of preservative may play good role $(9,17-18)$.

*Corresponding Author: Mailing address. Kamal Kanta Das, Lecturer Department of Microbiology, Stamford University Bangladesh, 51 Siddeswari Road, Dhaka 1217, Bangladesh, Bangladesh; E-mail: kkanta_36@yahoo.com.
The most common food borne pathogenic bacteria are Bacillus cereus, Clostridium botulinum, Escherichia coli, Shigella spp., Salmonella spp., Vibrio parahaemolyticus, Staphylococcus aureus, Campylobacter jejuni, Streptococcus pyogenes, Listeria monocytogenes etc. (1). Microbial contamination of juice can heavily infected the fetus, leading to spontaneous abortion, stillbirths, or sepsis in infancy (1). Coliforms, faecal coliforms contamination may come from the water used for juice preparation where environmental fomites may have a role in spreading of Salmonella spp., Shigella spp., Vibrio spp., Escherichia coli, and other diseases causing microbes $(1,18-19)$. Sometime growth of spoilage yeasts, such as Saccharomyces cerevisiae, Candida lipolytica and Zygosaccharomyces spp. can changes in $\mathrm{pH}$ which make juice more susceptible growth of pathogens $(1,18$, 20). The existence of microorganisms and their parts including bacterial toxin or poisonous protein of certain foods can cause food borne illness and also responsible for food spoilage $(14,18)$. Consequently, commercially available juice could be maintaining their quality by following different recommended guidelines like FDA (Food and Drug Administration), FAO (Food and Agriculture Organization).

Dhaka is one of the densely populated city and have hot climate during summer resulting in increased consumption of fruit juices which may consequently result in food borne illnesses. So maintaining the quality of processed fruit juices is important issue at present. In order to develop awareness among the people about fruit juices in transmitting diseases this study was attempted to 
analyse the microbiological status of some brands of fruit juice processed and sold in Dhaka, Bangladesh.

\section{MATERIALS AND METHODS}

Sampling and sample processing. Five different fruit juice samples from four different brands were used in this study within a time frame of November 2017 - March 2018. Samples were randomly collected from different super shops in Dhaka city. Dates of manufacturing and expiry were checked prior to microbiological tests. Prior to the microbiological assay for the estimation of bacterial and fungal load, samples were well mixed with normal saline (in 1:10 ratio). Serial dilutions were then consecutively prepared up to $10^{-5}(21)$.

Enumeration of total viable bacteria and fungi . An aliquot of $0.1 \mathrm{ml}$ of each suspension from the dilution $10^{-2}$ and $10^{-4}$ was introduced onto the nutrient agar (NA) plates and Sabouraud dextrose agar (SDA) plates by means of spreading in order to isolate and quantify the total viable bacterial count (TVBC) and fungi, respectively $(18,21,24)$. The NA plates were incubated at $37{ }^{\circ} \mathrm{C}$ for 18 to 24 hours and the SDA plates were incubated at $25^{\circ} \mathrm{C}$ for 48 to 72 hours, respectively.

Enumeration of specific pathogens. From the dilution of $10^{-2}$ of each sample, $0.1 \mathrm{ml}$ of suspension was spread onto MacConkey agar, mannitol salt agar (MSA), and Cetrimide agar for the enumeration of Escherichia coli, Staphylococcus spp., Pseudomonas spp., consecutively. All the plates were incubated at $37^{\circ} \mathrm{C}$ for 24 hours. Appearance of the typical colonies such as pink colonies on MacConkey agar, yellow colonies on MSA, colonies with greenish pigmentation on cetrimide agar, was analytical for the growth of E. coli or Klebsiella spp., Staphylococcus spp., Pseudomonas spp., consecutively $(18,21)$. Finally the confirmative biochemical tests were conducted to ensure the identity of the isolates $(1-2,22-24)$. Enumeration of bacterial load was performed by standard method (25).

\section{RESULTS AND DISCUSSION}

Refreshing drinks including the fruit juices are very popular among the people of all ages around the world. Also in Bangladesh, ready to eat refreshing fruit juice or sherbet is becoming more and more popular as they are usually tastier than soft drinks. After several study on food products from local market, they concern about the food safety and security issues in Bangladesh $(1,2,22$, 23). Nevertheless, researchers reported that microbial contamination in raw juice could take place from principal sources: from the raw materials; during handling; and from the unhygienic storage conditions (2627).

Current investigation also showed a situation of huge microbial contamination in most of the samples. All samples were found to harbor the total viable bacteria within a range of $10^{2}-10^{6} \mathrm{cfu} / \mathrm{ml}$ (Table 1). Out of 20 (twenty) fruit juice samples only 7 (seven) exceeded the microbial limit (28-30). And total fungal count of tested samples was within a range of $10^{2}-10^{3} \mathrm{cfu} / \mathrm{ml}$. Here all the samples were found to have fungi in the acceptable limit (28-30). This study reported that total viable bacterial count in most of the mango and lichi juice samples was higher than the others packed juice due to the variation in $\mathrm{pH}$ or chemical composition because juice of orange, grape and apple contain low $\mathrm{pH}$.

Unlikely, pathogenic bacterial were found which were biochemically identified (Tables 1 and 2). Although fecal coliform, Salmonella spp. and Vibrio spp. was not encountered in any sample, only 6 samples were found to be contaminated with coliform within a range of $10^{1}-10^{2}$ $\mathrm{cfu} / \mathrm{ml}$. Staphylococcus spp. were found in all the samples

TABLE 1. Microbial load in the commercial juice samples

\begin{tabular}{cccccc}
\hline \multirow{2}{*}{$\begin{array}{c}\text { Juice } \\
\text { sample }\end{array}$} & \multicolumn{5}{c}{ Microbial load (cfu/ml) } \\
\cline { 2 - 5 } & Brand & $\begin{array}{c}\text { Total Viable } \\
\text { Bacteria }\end{array}$ & $\begin{array}{c}\text { Fungal } \\
\text { count }\end{array}$ & $\begin{array}{c}\text { Total } \\
\text { coliform }\end{array}$ & $\begin{array}{c}\text { Staphylococcus } \\
\text { spp. }\end{array}$ \\
\hline \multirow{5}{*}{ Mango } & A & $2.8 \times 10^{6}$ & $1.2 \times 10^{3}$ & $2.0 \times 10^{2}$ & $1.1 \times 10^{2}$ \\
& B & $1.9 \times 10^{5}$ & $1.5 \times 10^{3}$ & $4.2 \times 10^{2}$ & $2.1 \times 10^{3}$ \\
& C & $2.7 \times 10^{6}$ & $2.2 \times 10^{3}$ & 0 & $2.6 \times 10^{3}$ \\
Lichi & D & $5.3 \times 10^{6}$ & $2.5 \times 10^{3}$ & 0 & $1.1 \times 10^{2}$ \\
& A & $1.3 \times 10^{6}$ & $1.2 \times 10^{3}$ & $2.0 \times 10^{2}$ & $2.1 \times 10^{3}$ \\
& B & $1.2 \times 10^{4}$ & $2.5 \times 10^{3}$ & 0 & $2.6 \times 10^{3}$ \\
Orange & C & $3.5 \times 10^{4}$ & $1.1 \times 10^{2}$ & 0 & $1.1 \times 10^{2}$ \\
& D & $4.2 \times 10^{5}$ & $2.1 \times 10^{3}$ & 0 & $2.1 \times 10^{3}$ \\
\hline \multirow{5}{*}{ Grape } & A & $4.5 \times 10^{5}$ & $2.6 \times 10^{3}$ & $2.1 \times 10^{2}$ & $2.6 \times 10^{3}$ \\
& B & $2.3 \times 10^{3}$ & $1.5 \times 10^{2}$ & 0 & $1.1 \times 10^{2}$ \\
& C & $3.5 \times 10^{4}$ & $2.1 \times 10^{2}$ & 0 & $2.1 \times 10^{3}$ \\
& D & $1.4 \times 10^{3}$ & $1.1 \times 10^{2}$ & 0 & $2.6 \times 10^{3}$ \\
\hline \multirow{5}{*}{ Apple } & A & $3.5 \times 10^{4}$ & $2.2 \times 10^{2}$ & 0 & $2.1 \times 10^{2}$ \\
& B & $3.2 \times 10^{4}$ & $2.6 \times 10^{2}$ & $1.0 \times 10^{2}$ & $2.6 \times 10^{3}$ \\
& C & $2.5 \times 10^{3}$ & $1.1 \times 10^{3}$ & $1.1 \times 10^{1}$ & $1.1 \times 10^{2}$ \\
\hline
\end{tabular}

Fecal coliform, Staphylococcus spp. and Vibrio spp. were absent in all the samples.

Microbiological standard recommended for any types of juice (Gulf Standards (29)

Maximum bacterial load anticipated: Total viable count $-5.0 \times 10^{3}$, Coliform -10 , Fecal coliform -0 , Staphylococci -100

Maximum bacterial load anticipated: Total viable count $-1.0 \times 10^{4}$, Coliform -100 , Fecal coliform -0 , Staphylococci $-1.0 \times 10^{3}$ 
TABLE 2. Confirmative biochemical tests for the isolates

\begin{tabular}{|c|c|c|c|c|c|c|c|c|c|c|}
\hline \multirow{2}{*}{$\begin{array}{l}\text { Assumed } \\
\text { Organism }\end{array}$} & \multicolumn{3}{|c|}{ TSI } & \multirow{2}{*}{  } & \multirow{2}{*}{ 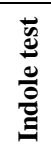 } & \multirow{2}{*}{$\begin{array}{l}\vec{y} \\
\stackrel{\vec{g}}{\Sigma}\end{array}$} & \multirow{2}{*}{$\frac{\vec{s}}{\vec{s}}$} & \multirow{2}{*}{ 苞 } & \multirow{2}{*}{ 胥 } & \multirow{2}{*}{ 总 } \\
\hline & $\begin{array}{l}\vec{\Xi} \\
\text { ज̆ }\end{array}$ & $\stackrel{E}{E}$ & 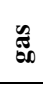 & & & & & & & \\
\hline Klebsiella spp. & $\mathrm{Y}$ & $\mathrm{Y}$ & - & - & - & - & - & - & - & + \\
\hline Staphylococcus spp. & $\mathrm{Y}$ & $\mathrm{R}$ & + & + & - & + & - & + & + & - \\
\hline
\end{tabular}

TSI $=$ Triple Sugar Iron Test

$\mathrm{Y}=$ Yellow (Acid)

$\mathrm{R}=\mathrm{Red}$ (Alkaline)

$\mathrm{MR}=$ Methyl red

$\mathrm{VP}=$ Voges Prokauer

in a range of $10^{2}-10^{3} \mathrm{cfu} / \mathrm{ml}$. The presence of coliforms and Staphylococcus spp. in juice may be introduced due to improper processing as they are recognized to be the natural flora of fruits (31).

\section{CONCLUSIONS}

This work assessed the bacteriological condition of available local refreshing drinks. Cheap price and ease of availability make these drinks and sherbets highly demanding to people of all income groups. It was also found that the presence of pathogenic organisms such as total coliform, salmonella and fungus were within the acceptable range and considered safe for consumption. The Government-authorized institute such as Bangladesh Council of Scientific and Industrial Research (BCSIR) and BSTI should undertake preemptive investigations to check the microbial and chemical quality of the fruit juices as well as initiate increased public awareness programs on contaminated and adulterated juices. The present study revealed that all the studied samples had a higher microbial load than the specification set for these kind of drinks. Continuous scrutinizing of the quality of such drinks for human consumption is suggested to evade the outbreak of any bacterial pathogen.

\section{ACKNOWLEDGEMENT}

We thank Microbiology Laboratory, Stamford University Bangladesh for laboratory facilities, technical assistance and financial aid.

\section{REFERENCES}

1. Rahman T, Hasan S, Noor R. 2011. An Assessment of Microbiological Quality of Some Commercially Packed and Fresh Fruit Juice Available in Dhaka City: A Comparative Study. Stam. J. Microbiol. 1 (1): 13-18.

2. F Tasnim, Hossain AM, Nusrath S, Hossain KM, Das L, Haque FKM. 2010. Quality assessment of industrially processed fruit juices available in Dhaka city, Bangladesh. Malaysian J. Nutri.16 (3): 431-438.

3. Tambekar DH, Jaiswal VJ, Dhanorkar DV, Gulhane PB, Dudhane MN. 2009. Microbial quality and safety of street vended fruit juices: A case study of Amravati city. Int. J. Food Safety. 10: 72-76.
4. Ghenghesh KS, Belhaj K, El-Amin WB, Nefathi E, Zalmum A. 2005 Microbiological quality of fruit juices sold in Tripoli-Libya. Food Cont. J. 16: 855-858.

5. Franke AA, Cooney RV, Henning SM \& Custer LJ. 2005. Bioavailability and antioxidant effects of orange juice components in humans. J. Agric. Food Chem. 53 (13): 5170-8.

6. Kurowska EM, Spence JD, Jordan J, Wetmore S, Freeman DJ, Piché LA, et al. 2000. Cholesterol-raising effect of orange juice in subjects with hypercholesterolemia. Am. J. Clin. Nutr. 72: 1095-100.

7. Deanna MM, Jeffrey SB. 2007. Acid-alkaline balance: role in chronic disease and detoxification. Altern. Therapies. 13 (4): 62-65.

8. Rowe RC, Sheskey PJ, Cook WG, Fenton ME. 2012. Handbook of pharmaceutical excipients. Pharmaceutical Press, London.

9. Anand SP, Sati N. 2013. Artificial preservatives and their harmful effects: looking toward nature for safer alternatives. Int. J. Pharm. Sci. Res. 4: 24962501.

10. Fasoyiro SB, Ashaye OA, Adeola A, Sumeul FO. 2005. Chemical and storability of fruits flavored drinks. World. J. agric. Sci. 1: 165-168.

11. Juhaniakova L, Kacaniova M, Petrova J, Kunova S, Pavelkova A, Bubkova A. 2013. Microbiological quality of confectionary products. J. Microbiol. Biotech. Food. Sci. 2: 1244-1251.

12. Muinde OK, Kuria E. 2005. Hygienic and sanitary practices of vendors of street foods in Nairobi, Kenya. Afri. J. Food Agri. Nutr. Devo. 5 (1): 1-13.

13. Chumber SK, Kaushik K, Savy S. 2007. Bacteriological analysis of street foods in Pune. Indian J. Public Health. 51 (2): 114-6.

14. Abadias M, Usall J, Anguera M, Solsona C, Vias I. 2008. Microbiological quality of fresh minimally processed fruit and vegetables, and sprouts from retail establishments. Intl. J. Food Microbiol. 123 (1-2):121-129.

15. Olorunjuwon BO, Temitope BK, Muibat FO, Afolabi O. 2014 Microbiological quality of some locally produced fruit juices in Ogun state, South Western Nigeria. J. Microbiol. Res. 2 (1): 1-8.

16. Sharma PU. 2013. Bacteriological analysis of street vended fruit juices in Vidharbha. Int J Curr. Microbiol. Appl. Sci. 2 (5): 178-183.

17. Esteve MJ, Frigola A, Rodrigo C, Rodrigo D. 2005. Effects of storage period under variable conditions on the chemical and physical composition and color of Spanish refrigerated orange juices. Food Chem. Toxico. 43: 1413-1422.

18. Khanam N, Mia MY, Zubair A, Real MKH. 2018. Microbial and chemical quality analysis of industrially processed mango juice available in Tangail Sadar Uazila, Bangladesh. Annals. Food Sci. Techn. 19 (2): 333-340.

19. Doyle MP, Beuchat LR, Montville TJ. 2001. Food Microbiology. American Society for Microbiology, ASM Press, Washington DC.

20. FDA (Food \& Drug Administration). 2001. Bacteriological Analytical Manual Online. FDA, USA.

21. Das KK, Fatema KK, Nur IT, Noor R. 2013. Prevalence of microorganisms in commonly used cosmetics samples in Dhaka metropolis. J. Pharma. Sci. Inno. 2 (6): 7-9.

22. Senjuti JD, Feroz F, Tahera J, Das KK, Noor R. 2014. Assessment of microbiological contamination and the in vitro demonstration of the antibacterial traits of the commonly available local fruit blend within Dhaka Metropolis. J. Pharmacog. Phytoch. 3 (1): 73-77.

23. Tahera J, Feroz F, Senjuti JD, Das KK, Noor R. 2014. Demonstration of Anti-Bacterial Activity of commonly available Fruit Extracts in Dhaka, Bangladesh. Am. J. Microbiol. Res. 2 (2):68-73.

24. Cappuccino JG, Sherman N. 1996. Microbiology- A Laboratory Manual, $7^{\text {th }}$ ed. The enjamin/ Cummings Publishing Co. Inc., California.

25. American Public Health Association. 1998. Standard methods for the examination of water and wastewater. American Public Health Association, Washington DC. 
26. Afroz H, Sultana F, Fakruddin M, Kamrunnahar, Khan ZUM, Datta S. 2013. Isolation of Escherichia coli and Staphylocccus aureus from full cream power milk sold under market conditions at Dhaka, Bangladesh and their antibiotic susceptibility. J. Adv. Sci. Res. 4 (3):27-31.

27. Bramley AJ, McKinnon CH. 1990. The microbiology of raw milk. Elsevier Applied Sci., London.

28. UNBS. 2009. Uganda Standard, Fruit Juices and Nectars-Specification.
29. Gulf Standards. 2000. Microbiological criteria for foodstuffs. Part 1. GCC, Riyadh, Saudi Arabia.

30. Braide W, Oranusi SU, Otali CC. 2012. Microbiological status of processed fruit juice sold in the commercial city of Onitsha. Schol. J. Bio. Sci. 1 (3): 2530.

31. Frazier WC, Westhoff DC. 1998. Food microbiology 4th ed, Mc Graw Hill, New Delhi. 